\title{
PENELITIAN COVID-19 DI INDONESIA
}

\author{
Mia Lasmi Wardiyah \\ Fakultas Ekonomi dan Bisnis Islam \\ Universitas Islam Negeri Sunan Gunung Djati Bandung \\ Email : mialasmiwardiyah@ymail.com
}

\begin{abstract}
ABSTRAK
Covid-19 atau Corona Virus Disease 2019 pertama kali dilaporkan di Wuhan, Tiongkok, pada akhir 2019, virus ini telah menyebar ke sejumlah Negara, termasuk di Indonesia. WHO telah menetapkan Corona Virus Disease 2019 (Covid-19) sebagai pandemik global. muculnya pandemik virus ini mampu melumpuhkan aktivitas semua kalangan masyarakat yang dilakukan di luar rumah. Adapun dengan penyakit berbahaya lainnya yakni kanker. Kanker menjadi masalah kesehatan serius baik dinegara maju maupun berkembang. Maka dari itu peneliti melakukan penelitian ini guna mengetahui berapakah data yang terkena, meninggal, dan sembuh karena Covid 19 serta bagaimana perhitungan regresi sederhana dan berganda dari data tersebut serta bagaimana komparasi atau perbandingan antara Covid-19 dengan Kanker. Dengan menggunakan data sekunder dan metode analisis statistic yang bersifat komparatif didapatkan hasil relasi angka kematian akibat virus Corona terus bertambah. Sebuah penelitian terbaru menunjukkan, orang-orang yang menderita kanker dan terjangkit Covid-19 punya risiko kematian tiga kali lebih tinggi dibanding mereka yang tidak.
\end{abstract}

Kata Kunci : Covid, kanker, penyakit, virus. 


\section{PENDAHULUAN}

Sejak pertama kali dilaporkan di Wuhan, Tiongkok, pada akhir 2019, virus Corona telah menyebar ke sejumlah Negara, termasuk di Indonesia. WHO telah menetapkan Corona Virus Disease 2019 (Covid-19) sebagai pandemik global. Pada tanggal 8 Januari 2021 jumlah kasus konfirmasi Covid-19 di Indonesia adalah 808.000 jiwa.

Kejadian muculnya pandemik virus Corona atau Covid-19 ini mampu melumpuhkan aktivitas semua kalangan masyarakat yang dilakukan di luar rumah. Corona virus merupakan keluarga besar virus yang menyebabkan penyakit ringan sampai berat, seperti pilek sampai dengan yang serius seperti $M E R S$ dan SARS. Penularannya dari hewan ke manusia (zoonosis) dan penularan dari manusia ke manusia sangat terbatas, Masa pandami Covid-19 tidak bisa dikendalikan secara cepat sehingga membutuhkan penatalaksanaan yang begitu tepat baik dari pemerintah maupun masyarakat. Salah satu pencegahan untuk memutus penularan Covid19 yang diimbau oleh pemerintah adalah tetap tinggal dirumah. Hal tersebut membatasi penulis untuk melakukan penelitian secara langsung sehingga penelitian dilakukan berupa tinjauan kasus.

Tinjauan kasus mengenai perbandingan antara Covid-19 dengan kanker. Kanker merupakan istilah umum untuk pertumbuhan sel tidak normal, kondisi yang tumbuh sangat cepat, tidak terkontrol dan tidak berirama yang dapat menyusup ke jaringan tubuh yang normal, dan akhirnya menekan perkembangan jaringan yang normal. Kanker menjadi masalah kesehatan serius baik di negara maju maupun berkembang. Kanker merupakan penyebab utama kematian di seluruh dunia dan menyumbang 7,6 juta kematian, sehingga jumlah kematian yang disebabkan kanker mencapai 13\% dari semua kematian (WHO, 2008). Maka dari itu kami melakukan penelitian berapakah data yang terkena, meninggal, dan sembuh karena Covid 19 serta bagaimana perhitungan regresi sederhana dan berganda dari data tersebut serta bagaimana komparasi atau perbandingan antara Covid-19 dengan Kanker. Seperti yang kita ketahui bahwa maksud dari pengadakan penelitian adalah untuk mengumpulkan, mengolah, serta menganalisa data yang secara sistematis dan efisien untuk memecahkan suatu masalah. Selain itu, maksud dari penelitian adalah untukmengaplikasikan pengetahuan atau menerapkan ilmu statistik yang di dapat selama duduk di bangku perkuliahan tentang metode dan kegunaan statistik.

\section{Metode Penelitian}

Menurut Sugiyono (2017:3), "metode penelitian pada dasarnya merupakan cara ilmiah untuk mendapatkan data dengan tujuan dan kegunaan tertentu". Menurut Nana Syaodih Sukmadinata (2005: 55), penelitian expost facto meneliti hubungan sebab akibat yang tidak dimanipulasi atau diberi perlakuan (dirancang dan dilaksanakan) oleh peneliti dan dilakukan terhadap program, kegiatan, kejadian yang telah berlangsung atau telah terjadi. Data dalam penelitian ini bersifat data sekunder, yaitu data yang diperoleh peneliti dari sumber yang sudah ada berupa laporan dari Kementerian Kesehatan Republik Indonesia. Penelitian ini bersifat komparatif dan bersifat asosiatif. Metode analisis yang digunakan pada penelitian ini yaitu metode analisis dengan regresi linear. Analisis regresi adalah salah satu analisis statistik yang mempelajari hubungan antara dua atau lebih variabel kuantitatif sehingga 
satu variabel dapat diramalkan (predicted) dari variable lainnya.

Pada analisis regresi linear diasumsikan berlakunya bentuk hubungan linear dalam parameter. Analisis regresi berganda adalah suatu metode untuk meramalkan nilai pengaruh dua variabel independen atau lebih terhadap satu variabel dependen. Lebih mudahnya yaitu untuk membuktikan ada tidaknya hubungan antara dua variabel atau lebih dari dua variabel independen $\mathrm{X} 1, \mathrm{X} 2$, $\mathrm{X} 3, \ldots . ., \mathrm{Xi}$ terhadap satu variabel terikat $\mathrm{Y}$.

Persamaan umum analisis regresi:

$$
Y=\beta X+\varepsilon(\mathbf{1})
$$

\section{Dimana:}

$$
\mathbf{Y}=\text { Variabel dependen }
$$

$\boldsymbol{\beta}=$ Parameter

$\mathbf{X}=$ Variabel Independen

$\mathrm{E}=$ Error

Menurut Drapper dan Smith (1992) hubungan antara satu variabel dependen dengan satu atau lebih variabel independen dapat dinyatakan dalam regresi linier berganda. Metode komparatif menurut Sugiyono (2014:54) adalah penelitian yang membandingkan keadaan satu variabel atau lebih pada dua atau lebih sampel yang berbeda, atau dua waktu yang berbeda. Dalam penelitian ini peneliti ingin membandingkan virus Covid-19 dengan penyakit kanker dengan melakukan studi komparasi. Nana Sukmadinata (2008:56) mengatakan bahwa penelitian komparatif diarahkan untuk mengetahui apakah antara dua atau lebih dari dua kelompok ada perbedaan dalam aspek atau variabel yang diteliti. Dalam penelitian ini tidak ada pengontrolan variable, maupun manipulasi atau perlakuan dari peneliti.

Hasilnya dianalisis secara statistik untuk mencari perbedaan diantara variabel-variabel yang diteliti. Teknik analisis komparasional adalah salah satu teknik analisis kuantitatif atau salah satu teknik analisis statistik yang digunakan untuk menguji hipotesis mengenai ada tidaknya perbedaan antar variabel yang sedang diteliti.

\section{HASIL DAN PEMBAHASAN}

Kasus positif virus Corona atau Covid-19 di Indonesia pertama kali terdeteksi pada Senin (2/3). Pertama kali diumumkan oleh Presiden Joko Widodo. Sejak hari itu, jumlah kasus positif Corona semakin bertambah dari hari ke hari. Ada pasien yang meninggal dunia, banyak juga yang dinyatakan negatif dan akhirnya sembuh.Setiap hari, Merdeka.com terus memantau perkembangan kasus virus Corona di Indonesia. Kami akan memperbarui data terkini jumlah kasus virus Corona di Indonesia. 


\section{Tabel 1}

Data Perkembangan Kasus per-hari di bulan Agustus 2020

\begin{tabular}{ccc}
\hline Positif & Sembuh & Meninggal \\
\hline 66.417 & 59.052 & 2.287 \\
\hline \multicolumn{3}{c}{ Sumber: Covid19.go.id }
\end{tabular}

Berdasarkan dari data yang didapatkan dari 31 hari pada bulan Agustus 2020, dilakukan prosedur analisis regresi dan pengujian hipotesis:

Tabel 2

Survey (random) untukmengumpukan data variable bebas $\left(\mathrm{O}_{1}\right)$

kemudian variable terikat $\left(\mathrm{O}_{2}\right)$

\begin{tabular}{ccccccccccc}
\hline $\mathbf{X}$ & $\mathbf{Y}$ & $\mathbf{X}^{2}$ & $\mathbf{Y}^{2}$ & $\mathbf{X Y}$ & $\mathbf{X i}$ & $\mathbf{i}$ & $\sum \mathbf{Y}$ & $\sum \mathbf{Y}^{2}$ & $\begin{array}{r}\mathbf{X}^{2}-\left(\sum \mathbf{Y}\right) \\
2 / \mathbf{n i}\end{array}$ \\
\hline 66147 & 2287 & 148086043 & 177903 & 5038539 & 66147 & & 2287 & 177903 & \\
\hline
\end{tabular}

\section{Banyak}

\section{kelompok}

$\mathrm{X}: \mathrm{k}=$

Menguji linieritas regresi dan signifikansi atau kebermaknaan koefisisen regresi 1)
Ho: $Y=\beta o+\beta x+\varepsilon$

Ha: $Y \neq \beta \mathrm{O}+\mathrm{Bx}+\varepsilon$

2)

Ho: $\beta=0$

Ha: $\beta \neq 0$
Menyusun hipotesis linieritas regresi

(Regresi linier)

(Regresitidak linier)

Menyusun hipotesis kebermaknaan atau signifikansi regresi

(Koefisien regresi bermakna/signifikan)

(Koefisien regresi tidak bermakna atau signifikan)

3)

Menyusun persamaan regresi $\mathrm{Y}=\mathrm{bo}+\mathrm{Bx}$

$\mathrm{b}=\left(\left(\mathrm{n} \sum \mathrm{XY}\right)-\left(\sum \mathrm{X}\right)\left(\sum \mathrm{Y}\right)\right) /\left(\left(\mathrm{N} \sum \mathrm{X}^{2}\right)-\left(\sum \mathrm{X}\right)^{2}\right)$

bo $=25.03$

Persamaan regresi: $\mathrm{Y}=25.03+0.02 \mathrm{X}$

Menguji kebermaknaan atau signifikasi koefisien korelasi 
1) Menyusun hipotesis keberartian koefisien korelasi

Ho: $\mathrm{p}=0$ (Koefisien korelasi tidak bermakna/signifikan)

Ha: $\mathrm{p}>0$ (Koefisien korelasi positif dan bermaknalsignifikan)

2) Menghitung koefisien korelasi dan menguji signifikansinya

$\mathrm{r}=\left(\left(\sum \mathrm{XY}\right)-\left(\sum \mathrm{Y}\right)\left(\sum \mathrm{X}\right) / \mathrm{n}\right) / \sqrt{ }\left(\sum \mathrm{X}^{2}-\left(\sum \mathrm{X}\right)^{2 / n}\right)\left(\sum \mathrm{Y}^{2}-\left(\sum \mathrm{Y}\right)^{2} / \mathrm{n}\right)$

$\mathrm{r}=0.63$

3) Menghitung t observasi (to)

to $=\mathrm{r} \sqrt{ }((\mathrm{n}-2)) /\left(1-\mathrm{r}^{2}\right)$

to $=4.4$

4) Menetapkan derajat kebebasan (db) dan menentukan $t$ kritis (tk)

$\mathrm{db}=\mathrm{n}-2$

$\mathrm{db}=29$

$\mathrm{tk}=\mathrm{t}(1-1 / 2 \alpha ; \mathrm{db})=\mathrm{t}(0,95 ; 29)$

$\mathrm{tk}=1.69$

5) Mengambil keputusan analisis Tolak Ho jika to $>$ tk

Terima Ho jika to $\leq \mathrm{tk}$

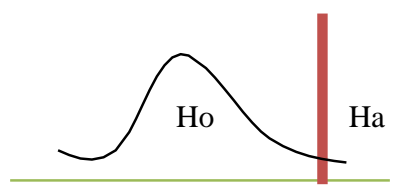

1.69

Gambar 1. Hasil Keputusan Analisis

Karena 4.4> 1.69 maka tolak Ho.

Artinya, terdapat korelasi linier positif antara positif corona dengan meninggal.

Analisis regresi ganda dua prediktor:

Tabel 3. Data observasi untuk X1, X2 dan $\mathrm{Y}$ secara berurut.

\begin{tabular}{rrrrcccccc}
\hline$\Sigma$ & $\mathbf{X}_{\mathbf{1}}$ & $\mathbf{X}_{2}$ & $\mathbf{Y}$ & $\mathbf{X}_{\mathbf{1}} \mathbf{X}_{\mathbf{2}}$ & $\mathbf{X}_{\mathbf{1}} \mathbf{Y}$ & $\mathbf{X}_{\mathbf{2}} \mathbf{Y}$ & $\mathbf{X}{ }^{2}$ & $\mathbf{X}{ }^{2}$ & $\mathbf{Y}^{2}$ \\
\hline 6 & 5 & $\vdots$ & 13033 & 503 & 459 & 148086 & 12443 & 177 \\
6147 & 9052 & 287 & 3979 & 8539 & 5672 & 043 & 0325 & 903 \\
\hline
\end{tabular}

Menguji linieritas masing-masing regresi sederhana X1 dengan X2 dengan $Y$ (atau diasumsikan linier) (uji linieritas masing- masing regresi sederhana menggunakan file regresi 1 predikator)

1) Hasil uji/asumsi linieritas regresi $Y=b o+b$ linier

2) Hasil uji/asumsi linieritas regresi $Y=b o+b$ linier

3) Analisis dilanjutkan dengan: 
Menyusun persamaan regresi ganda X1 dan X2 atas Y. Untuk mendapatkan nilai statistic, diperlukan jumlah Pasangan data: $\mathrm{n} 30$

$$
\begin{aligned}
& \sum X 1^{2}=\sum X 1^{2}-\left(\sum X 1\right)^{2} / n \\
& \sum X 2^{2}=\Sigma X 2^{2}-\left(\sum X 2\right)^{2} / \mathrm{n} \\
& \sum X 1 X 2=\sum X 1 X 2-\left(\sum X 1\right)\left(\sum X 2\right) / n \\
& \sum \mathrm{X} 1 \mathrm{y}=\Sigma \mathrm{X} 1 \mathrm{Y}-\left(\sum \mathrm{X} \mathbf{1}\right)\left(\sum \mathrm{Y}\right) / \mathrm{n} \\
& \sum \mathrm{X} 2 \mathrm{y}=\Sigma \mathrm{X} 2 \mathrm{Y}-\left(\sum \mathrm{X} 2\right)\left(\sum \mathrm{Y}\right) / \mathrm{n} \\
& \sum \mathrm{y}^{2}=9181,4
\end{aligned}
$$

Menyusun persamaan simultan

Mencari harga b1 dan b2: $\sum \mathrm{X}_{1}{ }^{2}$

$$
\begin{aligned}
& \mathrm{b} 1=\mathrm{D} 1 / \mathrm{D} \quad=858328752314,3 / 64164628408513,6 \\
& =0.013 \\
& \mathrm{~b} 2=\mathrm{D} 2 / \mathrm{D} \quad=973761875145,6 / 64164628408513,6 \\
& =0.015 \\
& \mathrm{bo}=\left(\sum \mathrm{Y}\right) / \mathrm{n}-\mathrm{b} 1\left(\sum \mathrm{X} 1\right) / \mathrm{n}-\mathrm{b} 2\left(\sum \mathrm{X} 2 / \mathrm{n}\right) \\
& =17.46
\end{aligned}
$$

Persamaan regresi $\mathrm{Y}=17.46+0.013 \mathrm{X} 2+0.015 \mathrm{X} 2$

Menguji signifikansi (koefisien) regresi ganda $\mathrm{X} 1$ dan $\mathrm{X} 2$ atas $\mathrm{Y}$;

1) Hipotesis statistik:

Ho : $\beta 1, \beta 2=0$ (Model persamaan regresi tidak signifikan)

$\mathrm{H} 1: \beta 1, \beta 2 \neq 0$ (Model persamaan regresi signifikan)

2) Statistik yang diperlukan $\mathrm{JK}(\mathrm{T})=\sum \mathrm{y}^{2}$

$\mathrm{db}(\mathrm{T})=\mathrm{n}-1 \mathrm{db}(\operatorname{Res})=2$

$\mathrm{JK}(\mathrm{T})=9181,4 \mathrm{db}(\mathrm{T})=30$

$\mathrm{db}(\operatorname{Res})=28$

$\mathrm{JK}(\operatorname{Reg})=\mathrm{b} 1\left(\sum \mathrm{X} 1 \mathrm{y}\right)+\mathrm{b} 2\left(\sum \mathrm{X} 2 \mathrm{y}\right)=5649$

$\mathrm{JK}(\operatorname{Res})=\mathrm{JK}(\mathrm{T})-\mathrm{JK}(\operatorname{Reg})=3532.4$

3) Rerata Jumlah Kuadrat (RJK)

$$
\begin{aligned}
& \mathrm{RJK}(\operatorname{Reg})=\mathrm{JK}(\operatorname{Reg}) / \mathrm{db}(\operatorname{Res})=5649 / 2 \\
& \mathrm{RJK}(\operatorname{Reg})=2824,5 \\
& \mathrm{RJK}(\operatorname{Res})=\mathrm{JK}(\operatorname{Res}) / \mathrm{db}(\operatorname{Res})=3532.4 / 28 \mathrm{RJK}(\operatorname{Res})=126.1
\end{aligned}
$$

4) F observasi (Fo)

$$
\begin{aligned}
& F_{O}=R J K(\operatorname{Reg}) / R J K(\operatorname{Res}) \\
& F_{O}=22.4
\end{aligned}
$$


Taraf signifikan: $\alpha=0,05$

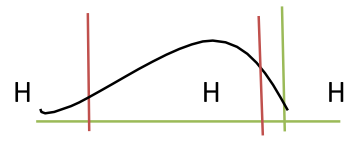

Fk1 Fk2

$\mathrm{Fk} 1=4,22$

$\mathrm{Fk} 2=0,25$

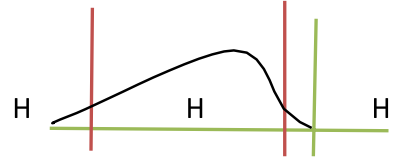

Gambar 2. taraf signifikan $(\alpha)$ dan menentukan F kritis (Fk)
4,22
0,25

Gambar 3. Menetapkan kriteria keputusan Analisis

Tabel 4. Tabel ANOVA

\begin{tabular}{|c|c|c|c|c|c|c|}
\hline \multirow{2}{*}{$\begin{array}{l}\text { Sumber } \\
\text { varians }\end{array}$} & \multirow{2}{*}{ JK } & \multirow[b]{2}{*}{$\mathbf{b}$} & \multirow{2}{*}{ RJK } & \multirow{2}{*}{ Fo } & \multicolumn{2}{|c|}{ Fkritis } \\
\hline & & & & & $\mathbf{F k}^{1}$ & $\mathbf{F k}^{2}$ \\
\hline Regresi (Reg) & 5649 & & 2824,5 & 22.4 & 4,22 & 0,25 \\
\hline Regresi (Res) & 3532.4 & 8 & 126.1 & & & \\
\hline Total (T) & 9181.4 & 0 & & & & \\
\hline
\end{tabular}

\section{5) Mengambil keputusan}

Fo $=4,22>0,25$

6) Menarik kesimpulan

Karena Ho ditolak, berarti model regresi X1 dan X2 atas $\mathrm{Y}$ signifikan.

Artinya persamaan regresi $Y=17.4+0,015 X 2$ dapat digunakan untuk memprediksi.

Angka kematian akibat virus corona terus bertambah. Sebuah penelitian terbaru menunjukkan, orang-orang yang menderita kanker dan terjangkit Covid-19 punya risiko kematian tiga kali lebih tinggi dibanding mereka yang tidak. Studi yang peneliti China publickasikan baru-baru ini mengumpulkan infor- masi dari 14 rumahsakit di Provinsi Hubei, Tiongkok, termasuk 105 pasien kanker dan 536 pasien nonkanker. Semuanya positif virus corona dengan rentang usia yang sama.

Hasil penelitian menemukan, pasien kanker lebih rentan terhadap dampak virus corona dan memiliki risiko kematian tiga kali 
lebih tinggi dibandingkan dengan pasien Covid-19 non-kanker. 'Medical Daily' melansir Macon.com melaporkan, pasien kanker dalam penelitian ini adalah yang berstatus parah seperti menjalani perawatan di ruang perawatan intensif atau menggunakan ventilator.

Pasien Covid-19 dengan kanker hematologi atau darah, kanker paru-paru atau kanker metastasis memiliki efek yang paling parah. Juga, pasien kanker non-metastatik punya kemungkinan kejadian yang sama dibanding pasien non-kanker.

Selain itu, pasien Covid-19 yang menjalani operasi kanker juga berisiko tinggi. Sementara yang menjalani radioterapi tipis harapan hidupnya. Tingkat risiko akan tergantung pada usia, jenis kanker, dan perawatan yang mereka terima.Temuan ini menunjukkan, pasien dengan kanker adalah populasi yang jauh lebih rentan dalam wabah

\section{COVID-19 saat ini}

Menurut data WHO, kanker merupakan salah satu penyakit kronis yang berisiko tinggi menimbulkan komplikasi serius akibat COVID19, selain penyakit jantung dan pem- buluh darah, diabetes, serta penyakit pernapasan kronis.

\section{SIMPULAN}

Kasus positif virus Corona atau Covid-19 di Indonesia pertama kali terdeteksi pada Senin (2/3). Pertama kali diumumkan oleh Presiden Joko Widodo. Sejak hari itu, jumlah kasus positif Corona semakin bertambah dari hari ke hari. Data yang kami teliti yaitu selama satu bulan, tepatnya pada bulan Agustus jumlah pasien yang terkena akibat Covid 19 yaitu 66.417 orang, sedangkan yang meninggal berjumlah 59.052, dan yang sembuh 2.287 .

Angka kematian akibat virus Corona terus bertambah. Sebuah penelitian terbaru menunjukkan, orang-orang yang menderita kanker dan terjangkit Covid-19 punya risiko kematian tiga kali lebih tinggi dibanding mereka yang tidak. Studi yang peneliti China publikasikan baru-baru ini mengumpulkan informasi dari 14 rumah sakit di Provinsi Hubei, Tiongkok, termasuk 105 pasien kanker dan 536 pasien non-kanker. Semuanya positif virus Corona dengan rentang usia yang sama.

\section{DAFTAR PUSTAKA}

Http://Covid19.Go.Id/ Diakses Tanggal 09-01-2021

Sugiyono. (2014). Metode Penelitian Kuantitatif, Kualitatif, Dan R\&D. Bandung. Penerbit Alfabeta

Sukmadinata, Nana Syaodih. 2016 Metode Penelitian Pendidikan. Bandung: Remaja Rosdakarya 